\title{
Danuta Kuźnicka
}

\section{Izraelski Hamlet Konrada Swinarskiego}

Podczas pracy nad Hamletem w Starym Teatrze w 1974 roku Konrad Swinarski kilkakrotnie przywoływał swoją inscenizację z 1966 w Teatrze Cameri w Tel Awiwie, co potwierdzają zarówno nagrania z prób', jak i późniejsze rozmowy z krakowskimi artystami². Reżyser nie był zadowolony z efektu swej pracy w Izraelu. Autorka monografii Swinarskiego Joanna Walaszek napisała wprost: „Hamlet sukcesem nie był. Po latach Swinarski sam oceniał przedstawienie dosyć krytycznie"3. Omawiając interpretację postaci Horacego, reżyser stwierdził, że „to jest jedna

\footnotetext{
1 Danuta Kuźnicka, oprac., ,Konrad Swinarski na próbie Hamleta", Pamiętnik Teatralny 28, z. 1 (1979): 3-52.

2 Józef Opalski, Rozmowy o Konradzie Swinarskim i „Hamlecie” (Kraków: Wydawnictwo Literackie, 1988). W książce Opalskiego znalazły się również przekłady dwóch recenzji z izraelskiej prasy, notatki Swinarskiego oraz wypowiedź Szimona Bara grającego w Tel Awiwie tytułową rolę.

3 Joanna Walaszek, Konrad Swinarski ijego krakowskie inscenizacje (Warszawa: Państwowy Instytut Wydawniczy, 1991), 81.
} 
z niewielu rzeczy, która tam wyszła w tamtym przedstawieniu”4, choć ze względu na jego krytyczny stosunek do własnych dokonań, można to zdanie traktować cum grano salis. Bez względu na to, jak udana była formuła inscenizacji w Teatrze Cameri, nie ulega wątpliwości, że traktował ją jako probierz swojej wizji dramatu i rozwiązań scenicznych. Wspominał: „w tej wersji, którą iks lat temu robiłem, usiłowałem wyjść od jednego punktu, który mi się potem w jakiś sposób sprawdził”, a także „interpretacja pewnych postaci, w tym utworze, którą ja częściowo wypróbowałem, powiedzmy, w poprzednim przedstawieniu"5.

O inscenizacji Swinarskiego w Tel Awiwie pisała niedawno Reut Barzilai, sytuując ją w kontekście innych izraelskich realizacji Hamleta ${ }^{6}$. Do rozważań na temat roli doświadczeń z Cameri w pracy Swinarskiego nad krakowską interpretacją tragedii Shakespeare'a powróciła z kolei Zuzanna Olbinska w pracy o nagraniach z prób w Starym Teatrze 7 . Olbinska formułowała swoje tezy, odwołując się do znanych materiałów dotyczących przedstawienia z 1966 roku. Podstawą tego artykułu są natomiast nieznane w Polsce recenzje i doniesienia prasy izraelskiej na temat premiery Hamleta ${ }^{8}$. Ich analiza ma wzbogacić obraz inscenizacji, by można było precyzyjniej ocenić, w jakim stopniu stanowiła ona etap rozwoju myśli Swinarskiego o tragedii Shakespeare'a. Pamiętać trzeba, że do pracy w Cameri reżyser przystępował już w znacznym stopniu koncepcyjnie przygotowany. Wiele dla niego znaczyły berlińskie rozmowy o Hamlecie z Dieterem Sturmem, podczas których rozważali możliwość odniesienia do tragedii historiozoficznych idei Hegla9 .

Próbując wyłuskać wpisane w recenzje tropy interpretacyjne, nakreślimy również kontekst recepcji wydarzenia. Ma to z kolei otworzyć możliwość analizy czynników wpływających na jego odczytanie. W przypadku Hamleta wyreżyserowanego przez Konrada Swinarskiego w Teatrze Cameri szczególnie istotne okazały się pytania dotyczące kryteriów wartościowania w komunikacji teatralnej. W jakiej mierze o ocenie przedstawienia decydują oczekiwania i kompetencje

4 Kuźnicka, „Swinarski na próbie”.

5 Kuźnicka, 8.

${ }^{6}$ Zob. Reut Barzilai, „Being European: Hamlet on the Israeli Stage”, Multicultural Shakespeare: Translation, Appropriation and Performance 21, no. 36 (2020): 27-53, https://doi.org/10.18778/2083-8530.21.03

7 Zuzanna Olbinska, „Od izraelskich notatek do krakowskich nagrań: Wizja Ducha ojca w niezrealizowanym Hamlecie Konrada Swinarskiego", Twórczość, nr 11 (2019): 80-93.

8 Ukazało się co najmniej dwadzieścia tekstów w językach: hebrajskim, jidysz, polskim, angielskim, niemieckim, francuskim, węgierskim, rumuńskim, hiszpańskim. W tekście wykorzystany został program teatralny i różnojęzyczne artykuły dotyczące przedstawienia ze zbiorów The Israeli Center for the Documentation of the Performing Arts Uniwersytetu w Tel Awiwie. Materiały tłumaczyli: Małgorzata Lipska (z hebrajskiego), Karo Wegner ( z jidysz), Biuro Tłumaczeń Varsovia (z niemieckiego, rumuńskiego, węgierskiego), Artur Kuźnicki (z hiszpańskiego) i Danuta Kuźnicka (z angielskiego i francuskiego).

9 O tej inspiracji świadczą słowa Swinarskiego z listu do żony Barbary Witek-Swinarskiej: . . . . ale koncepcja Sturma HEGEL!", Konrad Swinarski, ««Powinienem zmienić zawód». Z korespondencji Konrada Swinarskiego", Teatr 54, nr 7-8 (2000): 69, https://e-teatr.pl/powinienem-zmienic-zawod-z-korespondencji-konrada-swinarskiego-a195047.Zob. też Dieter Sturm, „Konrad Swinarski i teatr niemieckojęzyczny”, rozmawiała Małgorzata Dziewulska, tłum. Dorota Krawczyk-Janisch, Teatr 49, nr 5 (1994):7-15, https://e-teatr.pl/swinarski-i-teatr-niemiecki-rozmowa-z-dieterem-sturmem-a192438 
kulturowe odbiorców, w jakiej zaś ich indywidualna wrażliwość? Jak w różnych warunkach działają wpisane w inscenizację sposoby aktywizowania sfery intelektu i emocji widza?

\section{Przed premierą izraelskiego Hamleta}

Wystawienie tragedii Shakespeare’a w 1966 roku stało się niewątpliwie wydarzeniem w życiu kulturalnym Izraela. Przede wszystkim dlatego, że była to dopiero druga inscenizacja Hamleta, po izraelskiej prapremierze w 1946 w Teatrze Habima ${ }^{10}$. Sceny Tel Awiwu nieczęsto sięgały także po inne dzieła Stratfordczyka, a zamiar pokazania Otella i Ryszarda III odnotowywany był w 1965 z zaciekawieniem. Wykorzystany w Cameri nowy hebrajski przekład Hamleta autorstwa Abrahama Szlonskiego oceniano jako „doskonały”", „wybitny”"12, „wyrafinowany”13.

Pełną satysfakcję intelektualną dało nam wspaniałe tłumaczenie na hebrajski autorstwa Abrahama Slonsky'ego [!], które oczywiście pozostanie w literaturze hebrajskiej jako jedno z najlepszych i najbliższych oryginałowi ${ }^{14}$.

Zainteresowanie budziło też powierzenie reżyserii polskiemu twórcy, którego rangę artystyczną w pełni uznawano, wspominając zarówno bardzo dobre przyjęcie Kartoteki wystawionej rok wcześniej w teatrze Zawit, jak świetne inscenizacje w Niemczech oraz związki z Brechtem. Formułowano pewne wątpliwości, opowiadając się za ewentualnym wyborem inscenizatora izraelskiego lub Anglika, ale przeważały głosy przychylne Swinarskiemu' ${ }^{15}$. Emocje związane ze zbliżającą się premierą pobudziły informacje o zmianie w obsadzie roli tytułowej. Młody Oded Kotler po miesiącu prób uznał, że „nie podoła wyzwaniu”, dodając, że „,ze względu na proponowane skróty tekstu, nie jest gotowy na kompromis" i „albo zagra całą rolę, albo zrezygnuje"16. Kilka dni później inaczej kładł akcenty i tłumaczył, że „Swinarski oczekiwał nowego Hamleta, którego [aktor] musiałby dopiero poznać, a na to miał zbyt mało czasu”, rolę zaś mógłby zagrać, „gdyby oczekiwania reżysera były mniej złożone"17. Rezygnacja Kotlera stanowiła dla Swinarskiego poważne

\footnotetext{
10 Zob. też Barzilai, "Being European”.

$"$ Chusch, „Hamlet im Theatron Kameri" [Hamlet w Teatrze Cameri], Jedijot Chadaszot, 29 kwietnia 1966.

12 Gizella Marton, „Kameri Szinház: Hamlet” [Teatr Cameri: Hamlet], Új Kelet, 6 maja 1966

13 Manfred Geis, „Kammertheater: Hamlet” [Teatr Cameri: Hamlet], мв, 6 maja 1966, 9.

14 Aharon Gal, „Teatrul Hakameri: Hamlet" [Teatr Cameri: Hamlet], Adevărul, 2 g kwietnia 1966.

15 W latach pięćdziesiątych i sześćdziesiątych izraelskie sceny często zapraszały zagranicznych artystów, traktując to jako znak przynależności izraelskiego teatru do zachodniej kultury, zob. Barzilai, „Being European”, 32.

16 „Konrad Swinarski mechapes Hamlet" [Konrad Swinarski szuka Hamleta], Al Ha-Miszmar, 27 stycznia 1966.

17 "Oded Kotler we-Hamlet" [Oded Kotler i Hamlet], Jedijot Acharonot, 30 stycznia 1966.
} 
obciążenie, także psychiczne ${ }^{18}$. W trakcie poszukiwań nowego kandydata do roli reżyser wystawił w Cameri sztukę Arthura Kopita $O$ mój tato, biedny tato, mama powiesiła cię w szafie na śmierć... ${ }^{19}$. Wreszcie do obsady, jako Hamlet, dołączył Szimon Bar.

Praca z polskim twórcą stanowiła dla zespołu novum. W jednym $\mathrm{z}$ artykułów przedpremierowych czytamy, że Swinarski podczas prób posługiwał się trzema językami: niemieckim, angielskim i polskim, że wywoływał w aktorach poczucie niepewności, ale zapytany, wyjaśniał swoją interpretację ${ }^{20}$. Szimon Bar mówil, że „Swinarski pracuje bez określonego porządku, bez dyscypliny, zmienia sytuacje sceniczne 2-3 razy podczas próby, ale wie, czego chce, a to uspokaja aktora" ${ }^{21}$. $\mathrm{W}$ innym wywiadzie precyzował:

Swinarski pracuje inaczej niż reżyserzy lokalni czy gościnni, np. z usA. Nie przychodzi z gotowym egzemplarzem, ale pracuje na miejscu. Ma koncepcję, ale widzi, co się dzieje na scenie. Przemyśli to i wraca z uwagami ${ }^{22}$.

Michael Ohad przywołał w tym tekście również następujące wspomnienie:

Znajomy malarz, który był obecny na próbach do O mój tato, [biedny] tato..., opowiadał mi, że w ogólnym chaosie panującym na scenie podczas próby generalnej (na generalnej zawsze jest chaos) Swinarski, zamiast wybuchnąć, zamknął się w sobie, zniknął między rzędami foteli i ruszył przed siebie na czworakach. Potem uspokoił się, wstał, zaczął próbę od nowa i zapytał o to, jak jego mistrz, Bardini, radził sobie w Hajifie ${ }^{23}$. „Bardini?” - usłyszał w odpowiedzi - „Krzyczał wniebogłosy, klął i bluzgał w jidysz”. Swinarski odparł cichutko: „Ja nie umiem krzyczeć”24.

Podczas prób Hamleta Swinarski uważnie obserwował aktorów, zachęcał do poszukiwania rozwiązań i traktował z szacunkiem nawet te, które zamierzał odrzucić. Tak było z pomysłem Szimona Bara, aby Hamlet miał ręce pomalowane na czerwono, jakby skrwawione. Reżyser początkowo zgodził się na ten efekt, ale później się wycofał. Ohad zapisał, że podczas prób Horacy w scenie finałowej miał kopnąć ciało Hamleta i z poddańczym uśmiechem wręczyć koronę nowemu królowi. W tekstach popremierowych nikt tego profanującego gestu Horacego nie odnotował. Poszukiwanie odpowiednich środków wyrazu w pracy na

\footnotetext{
18 Swinarski, «"Powinienem zmienić zawód»", 69.

19 Prem. 26 lutego 1966.

20 Szraga Har-Gil, „Panim chadaszot le-Hamlet" [Nowa twarz Hamleta], Maariw, 1 kwietnia 1966.

${ }^{21}$ M.D., "Svinarsky dirige Hamlet" [Swinarski reżyseruje Hamleta], Aurora, 15 kwietnia 1966.

22 Michael Ohad, „Maszehu rakuw be-erec Denmark" [Coś się psuje w państwie duńskim], Haarec, kwiecień 1966.

23 Aleksander Bardini wyreżyserował sztukę Dürenmatta Frank v, prem. 22 września 1964, Teatr Miejski w Hajfie.

24 Ohad, "Maszehu rakuw".
} 
scenie, $\mathrm{w}$ bliskim kontakcie $\mathrm{z}$ aktorami i innymi członkami zespołu, zaskakiwało wszystkich, ponieważ nie było powszechną wówczas praktyką. Zastanowienie budził również fakt, że Swinarski „nie patrzy na zegarek”25. W wywiadzie przedpremierowym grający Klaudiusza Josef Jadin przygotowywał widzów na spektakl „nowoczesny” i „polityczny” i na „niekonwencjonalną” postać króla, który nie jest po prostu mordercą, bo mord, który popełnił, „symbolizuje koniec feudalizmu” 26 . Sygnalizował tym samym całkowicie nowe odczytanie dramatu, zapowiadające pogłębiony, historiozoficzny przekaz.

\section{Hamlet i inni}

Z lektury recenzji i artykułów opublikowanych po premierze wynika, że większość krytyków, zapewne również widzów, nie była przygotowana na tego rodzaju inscenizację. Oczekiwali zupełnie innego Shakespeare’a z pełnym przekonaniem, że to ich wizja dzieła jest „prawidłowa” i ,słuszna”.

Od tygodni z radością przygotowywaliśmy się do tego wzniosłego wieczoru, kiedy na nowo odczarujemy nieśmiertelne dzieło Shakespeare’a na deskach teatru Cameri, pod wodzą wybitnego polskiego reżysera. Jakże wielkie było nasze zdziwienie: wynudziliśmy się i jesteśmy wręcz oburzeni. [...] Problem ze strony reżysera - naszym zdaniem nie wynika $\mathrm{z}$ braku swobody, ale tkwi w tym, że inscenizacja utrzymana jest $\mathrm{w}$ duchu naturalistyczno-realistycznym, a każdą scenę chciało się „umiejscowić” w historii. Prawda jest taka, że idąc tą drogą, reżyser wykazał się konsekwencją - zresztą mówiliśmy, że Swinarski jest doskonałym rzemieślnikiem - ale dramat pozbawiony został wszystkiego, co szekspirowskie: liryczności, poetyckiego rozmachu, romantyczności i ludzkich uczuć27.

Uri Kejsari pisał, że „niepowodzenie wynika z zasadniczego podejścia i z aspiracji do komentowania Szekspira przy pomocy nowych wzorów, zamiast tego, aby być wiernym niewolnikiem wielkiego dramaturga" ${ }^{28}$. Boaz Ewron zwracał uwagę, że: „Tradycyjna interpretacja umożliwiłaby rozwinięcie ról i odnalezienie się w nich”. W konkluzji podkreślał:

Interpretacja jest ciekawa, ale nie wyjaśnia wszystkiego, co jest w tekście. Jeśli izraelski teatr porywa się na Hamleta, niech to zrobi bez rewolucyjnych interpretacji. Może sobie

\footnotetext{
25 Ohad.

26 Emanuel Bar-Kadma, „Panim chadaszot le-Hamlet” [Nowa twarz Hamleta], Jedijot Acharonot, 1 kwietnia 1966.

27 Marton, „Kameri Szinház: Hamlet”.

${ }^{28}$ Uri Kejsari, „Szekspir dnia powszedniego", artykuł z dziennika Izraelskie Nowiny i Kurier, 24 kwietnia 1966, cyt. za: Opalski, Rozmowy o Swinarskim, 268.
} 
na to pozwolić kultura, w której to jest zakorzenione. Izrael niech pozna prawdziwy dramat, w jego prostej postaci, i podstawowy tekst ${ }^{29}$.

Nie ma potrzeby komentować przekonania o istnieniu „właściwych” interpretacji dramatów i konieczności dochowania „wierności tekstowi”, skoro tego rodzaju argumenty powracają do dziś. Warto jednak w dyskusji toczonej onegdaj w Izraelu dostrzec potrzebę istnienia interpretacji niejako „kanonicznych”, stanowiących trwałe punkty odniesienia dla kolejnych podejść i wykładni. Uwagi związane z oczekiwaniem „właściwego” czy „prawidłowego” odczytania dotyczyły także aktorstwa i scenografii. W dostępnych recenzjach próby interpretacji zaobserwowanych środków artystycznych, w tym ekspresji aktorskiej, w wielu momentach nakładają się na takie właśnie normatywne myślenie.

Najwięcej uwagi krytycy poświęcali roli tytułowej, do której Swinarski starannie przygotował aktora teoretycznie. Jego praca spotykała się z właściwym odbiorem, gdyż Bar miał opinię intelektualisty. Zeew Raw-Nof pisał: „Bar był wśród naszych aktorów zawsze kimś specjalnym - dociekliwym i oczytanym. [...] najlepszymi przyjaciółmi [...] Bara są książki, nie te «lekkie», ale książki «wagi ciężkiej» - filozofia, psychologia, dramaty"30. Przystępując do roli duńskiego księcia, aktor czytał między innymi liczne przedmowy Granville-Barkera do Hamleta, oglądał filmy, słuchał nagrań. Z drukowanej w książce Opalskiego wypowiedzi Bara wydobyć można kilka rysów postaci, którą pragnął ukształtować na scenie ${ }^{31}$. Wiedział, że Hamlet nie jest doskonały i że nie jest wariatem. Miał świadomość, że do działania zmusza go nie chęć zemsty, lecz ból, jaki sprawia mu matka, i że ten ból wpływa na jego postrzeganie kobiet. Hamlet Bara miał także rozumieć motywacje Klaudiusza. Aktor mówił, że reżyser wymagał, by stworzył Hamleta impertynenckiego, nerwowego, walczącego z losem. Bardzo zaangażował się w rolę, która była niemałym wyzwaniem.

Krytycy przyjęli jednak jego kreację chłodno. „Szimon Bar nie był w stanie unieść ciężaru roli, mimo że jego gra była szczera, prostolinijna i powściągliwa”32. W innej recenzji czytamy, że „wprawdzie niezupełnie «deklamował», ale mówił zbyt monotonnie, zamiast odpowiednio reagować na meandry swoich myśli”33. Łączono to również z wprowadzonymi przez reżysera skrótami: „Swinarski wyciął długie monologi i pozostawił go smutnego, bez interpretacji przyczyn" ${ }^{34}$. Generalnie zauważono odmienność ujęcia postaci Hamleta i obniżenie tonacji gry.

\footnotetext{
29 Boaz Ewron, „Mawet u-mischar be-armon Elsinor" [Śmierć i handel na zamku w Elsynorze], Jedijot Acharonot, 24 kwietnia 1966 .

30 Zeew Raw-Nof, "En nous presentant Hamlet", L'information d'Israel, 29 kwietnia 1966.

31 Opalski, Rozmowy o Swinarskim, 265-267.

32 Eljakim Jaron, "Hamlet metumcat" [Hamlet skondensowany], Mabat Chadasz, 5 maja 1966.

33 Chusch, "Hamlet im Theatron Kameri".

34 Jaron, "Hamlet metumcat".
} 
Barowi zarzucano „brak wzniosłości”, a jego księcia nazywano wręcz „proletariackim”35. Próbowano tłumaczyć taką koncepcję „uwspółcześnianiem” i szczególną wizją Swinarskiego.

Wokół Hamleta nie zapada zasłona utkana z szeregu niezrozumiałych myśli i lęków wewnętrznych, wikłających się w ciągłych sprzecznościach. Hamlet w wizji Swinarskiego jest przedstawiony we współczesnym rytmie, w którym Szekspirowski bohater od początku pojawia się wyraźnie jako zbuntowany wobec nikczemności własnej matki i swojego wuja Klaudiusza, zabójcy jego ojca! [...] Szimon Bar [...] ubiera go w skórę zwykłego i stanowczego człowieka, który kochał swojego zamordowanego królewskiego ojca i dla niego bierze szpadę w dłoń, aby bronić prawdy i walczyć o ludzką sprawiedliwość. Oczywiście nie można powiedzieć, aby Szimon Bar przez cały spektakl prezentował się jednakowo, jednak nie do końca możemy zaakceptować jego nowoczesne podejście do interpretacji, które za bardzo oddala go od szekspirowskiego ducha Hamleta ${ }^{36}$.

Wśród krytyków bardziej wnikliwie analizujących rolę Bara byli tacy, którzy podkreślali jego aktorskie atuty niewykorzystane przez reżysera stawiającego na inne rozwiązania:

Swinarski uratował swoich aktorów - zgodnie z instrukcjami Hamleta - przed popisywaniem się, zadbał o niezmiennie dobre tempo dialogu i zmian sytuacji scenicznych, ale w ogólnej tendencji do „under-play” utracono wiele tekstu Shakespeare’a. Dotyczy to wszystkich elementów inscenizacji, ale szczególnie szkoda, że dotyczy roli samego Hamleta, ponieważ Szimon Bar (który jak dotąd sprawdził się tylko w zgoła odmiennym repertuarze) miał wiele doskonałych momentów. Posiada również (co u nas rzadkie) dobrze ukształtowany aparat i technikę mowy, dużą muzykalność, szybkość ruchu i młodzieńczą sylwetkę, która pasuje do jego bohatera. Ale jeśli reżyser pozwala mu zupełnie przypadkowo wypowiadać wielkie monologi półgłosem i ze spuszczonymi oczami lub krzyczeć na Ofelię jak na niesforne dziecko, którego nigdy nie kochał, to oczywiście nigdy nie osiągnie wrażenia, jakie na przykład wywarł Moissi w swojej eterycznej zadumie i całkowicie wyczerpującej interpretacji tekstu ${ }^{37}$.

I jeszcze jeden cytat:

Wizja tragedii objawia się w sposób pełny w Hamlecie granym przez Szimona Bara. Widziałem w Polsce podobnego Hamleta. Może właśnie polskość stanowi ten rys

\footnotetext{
35 Kejsari, "Szekspir dnia powszedniego", 270

${ }^{36} \mathrm{Gal}$, ,Teatrul Hakameri: Hamlet".

37 Geis, „Kammertheater: Hamlet", g. Alexander Moissigrał Hamleta m.in. w Deutsches Theater wreżyserii Maxa Reinhardtaw19og.
} 
charakterystyczny. Szimon Bar pozbawiony jest romantyzmu i zewnętrznych oznak tragiczności. Głos ma oschły, diapazon niezbyt szeroki. Jest jednobarwny głosowo, ale też skupiony, poważny, przygotowany ${ }^{38}$.

Bez względu na kontrowersje, jakie budziła kreacja Bara, z opinii krytyków wynika, że aktor stworzył oryginalną, odbiegającą od tradycji postać, która stanowiła punkt ciężkości ogólnej interpretacji dramatu. Niemieckojęzyczny recenzent „Jediot Chadaszot" uchwycił jeden z kluczowych elementów koncepcji Swinarskiego, sprawę relacji księcia i Klaudiusza, którą reżyser chciał traktować jako wyznacznik podobieństwa ich koncepcji politycznych. O Szimonie Barze napisał:

Fakt, że początkowo był powściągliwy, wzmógł wrażenie, że mamy tu do czynienia z „działaniami zasadniczymi” i „działaniami państwowymi”. Również dlatego, że jego przeciwnik Klaudiusz, nowy król, nie został wykreowany przez Josefa Jadina jako łotr, lecz raczej jako ktoś, kto zgodnie z obyczajami renesansowego księcia dopuścił się wprawdzie zbrodni, ale poza tym jako monarcha prowadzi rozważnie interesy państwa. Poza tym, jako osoba, właściwie nie wywołuje odrazy. Innymi słowy, jest politykiem. [...] Podsumowując, ten król jest sympatyczny ${ }^{39}$.

Jednym z najistotniejszych czynników, które wpływają na możliwość odczytania przez widza znaczeń wpisanych w inscenizację, jest ranga artystyczna uruchomionych środków, w tym aktorskich. Relacja Hamleta i Klaudiusza miałaby prawdopodobnie większą szansę na pogłębioną interpretację przy szczęśliwszych możliwościach obsadowych. Trudno jednak rozstrzygać, czy o kłopotach z odczytaniem koncepcji reżysera decydowała nieprzekonująca gra aktora, czy też zbyt wygórowane oczekiwania widzów. Uwagi o grze Jadina w roli króla Klaudiusza formułowano krótko, wręcz zdawkowo. Jedni prawili komplementy: „Jadin interpretuje Klaudiusza - króla zabójcę - z talentem i zrozumieniem, odkrywając jego obłudny charakter i jednocześnie bojaźń wobec zemsty niebios”40. Albo:

Jadin jako król Klaudiusz był doskonały w każdym momencie swojej gry. Był nie tylko majestatyczny w swoim „exterieur”, lecz jednolity w swoim „interieur”, jako królobójca, rzekomo oddany ojciec Hamleta ${ }^{41}$.

Być może jednak pochlebne recenzje wynikały, jak to często w teatrze bywa, $\mathrm{z}$ wysokiej pozycji aktora w Cameri? Recenzentowi węgierskojęzycznego dziennika

\footnotetext{
${ }^{38}$ [Ezra Zusman?], "Hamlet ha-rewii szeli" [Mój czwarty Hamlet], Dawar, 29 kwietnia 1966.

39 Chusch, "Hamlet im Theatron Kameri”.

40 Gal, "Teatrul Hakameri: Hamlet”.

${ }^{41}$ Fabian Schlang, "Hamlet", Izraelskie Nowiny i Kurier, 29 kwietnia 1966.
} 
„Új Kelet” nie przeszkadzała ona w wyrażeniu oceny nieprzychylnej: „Negatywnie zaskakuje gra Orny Porat i Josefa Jadina. Dwoje głównych aktorów Cameri sprawia wrażenie, jakby byli do czegoś zmuszani”"42. Pomimo zróżnicowania opinii także w tym przypadku daje się zauważyć świadomość wykraczającej poza tradycję koncepcji roli. Recenzenci pisali: „Jadin (Klaudiusz) zbyt elegancki, aby był mordercą. Nie wiadomo, czego Hamlet od niego chce”43, „Klaudiusz wygląda jak dobry wujek, a nie jak czarny charakter" 44 , „Jadin w niewystarczającym stopniu wyjaśnił charakter postaci” 45 i wreszcie: „mówił wprawdzie wyraźnie, ale wydawało się, że gra zupełnie inną rolę niż przebiegłego mordercy brata, który może się uśmiechać i uśmiechać, a być prostakiem"46.

$\mathrm{O}$ innych postaciach partnerujących Hamletowi informacji jest również niewiele. Scenę w sypialni Gertrudy uznawano za jedną z lepszych w wykonaniu Bara, ale już odtwórczyni roli matki spotkała się ze zdecydowaną krytyką. „Uważamy, że utalentowana Orna Porat w zbyt małym stopniu zarysowuje perfidię i tchórzostwo swojej bohaterki” 47 . „W szczególności nie porywa nieruchoma twarz i stężały uśmiech Orny Porat"48. Padały też ostrzejsze słowa:

Orna Porat jako królowa Gertruda stała na scenie tak bezsensownie, jakby właśnie wskoczyła szybko w miejsce chorej koleżanki i nie miała dwóch miesięcy na postawienie się w sytuacji namiętnej kobiety, która pomaga w zabójstwie męża ${ }^{49}$.

Szimon Bar nie znalazł równorzędnej partnerki także w Szoszanie Szani obsadzonej w roli Ofelii. Trudno uwierzyć Mendlowi Kohansky'emu, kiedy wyznaje, że „dużym emocjonalnym przeżyciem jest gra Szoszany Szani w roli Ofelii. Scena szaleństwa jest niezrównanym studium chłodnej makabreski”"so. Pozostali recenzenci byli innego zdania. „Szani jako Ofelia nie odnalazła się podczas całego spektaklu w charakterze oszalałej córki Poloniusza"51.

W tym wszystkim największym zaskoczeniem była Ofelia. Nie była to Szoszana Szani, utalentowana, młoda aktorka, która z godnością zagrałaby tę najpiękniejszą postać

\footnotetext{
2 Marton, "Kameri Szinház: Hamlet”.

43 Jaron, "Hamlet metumcat".

44 Ewron, "Mawet u-mischar".

45 "Hamlet ha-rewii szeli".

46 Geis, „Kammertheater: Hamlet”.

47 Gal, "Teatrul Hakameri: Hamlet”.

48 Marton, „Kameri Szinház: Hamlet”.

49 Geis, „Kammertheater: Hamlet".

50 Mendel Kohansky, „Hamlet - sztuka siły”, tłum. Janina Cunnelley, przekład artykułu z Jerusalem Post, 29 kwietnia 1966, cyt. za: Opalski, Rozmowy o Swinarskim, 273-274

${ }^{51} \mathrm{Gal}$, ,Teatrul Hakameri: Hamlet".
} 
Szekspirowską, tę łagodność, liryczność, tę dziewczęcą miłość, jednoczesne ucieleśnienie radości i śmierci. Niestety, w wyobraźni polskiego reżysera Ofelia Szoszany Szani to krzepka, bezduszna, groteskowa kobieta ${ }^{52}$.

Nie miał dla aktorki litości Manfred Geis:

Do roli Ofelii zaangażowano specjalnie Szoszanę Szani, która sprawdziła się w programach kabaretowych. To wielka szkoda, że Teatr Cameri nie ma we własnych szeregach młodej aktorki, która mogłaby tu wystąpić. Ta Ofelia o bardzo spiczastej twarzy i przesadnie dziecinnym głosie jest już w swoich pierwszych scenach zupełnie nienaturalna, jest wszystkim poza cudem natury, którego Hamlet nie mógł przestać podziwiać, dopóki haniebny czyn matki nie sprawił, że stał się absolutnym wrogiem kobiet. W scenach szaleństwa należało zabronić pani Szani przesadnego szarżowania ${ }^{\mathbf{5 3}}$.

Ważną postacią w koncepcji Swinarskiego, o czym mówił też podczas prób w Krakowie, był Horacy pomyślany nie jako szlachetny powiernik księcia, lecz ktoś, kto usiłuje prowadzić własną grę polityczną. Z lektury recenzji wynika, że w Tel Awiwie nie udało się wydobyć z postaci pełni złożonych motywacji, ale zasadniczy, odmienny od tradycji wektor został zarysowany. Geis opisał Horacego jako „grzecznego”, „lojalnego” i „w zasadzie prostego człowieka, który później - jako jedyny ocalały - będzie dobrze służył zdobywcy Fortynbrasowi"54.

Zeew Rewach (Laertes) i Josef Graber (Horacy) jako przyjaciele Hamleta są pełni życia i energii i jako jedyni w odpowiedni sposób odgrywają swoje role. Ale bez skrajnych sentymentów: Horacy nie opłakuje zbyt długo śmierci Hamleta, tylko od razu oddaje hołd nowemu reżimowi pod wodzą Fortynbrasa ${ }^{55}$.

Mendel Kohansky opisał bliżej scenę finałową:

Kiedy śmiertelnie zraniony Hamlet osuwa się na ziemię, Horacy bierze go w swoje ramiona i, kładąc jego głowę na ciele królowej, życzy słodkiemu księciu - dobranoc. Ale w geście tym nie ma czułości i słowa pożegnania brzmią prawie jak szyderstwo. Wchodzi zwycięski Fortynbras, lustruje chłodnym okiem rzeź, w czasie gdy Horacy wyjaśnia wypadki i przekazuje mu koronę, która spadła z głowy nieżyjącego króla.

\footnotetext{
52 Marton, "Kameri Szinház: Hamlet”.

53 Geis, "Kammertheater: Hamlet”.

54 Geis.

55 Marton, „Kameri Szinház: Hamlet”.
} 
[...] Horacy jest człowiekiem praktycznym, zamiast opłakiwać zmarłych, będzie służył zwycięzcy ${ }^{56}$.

Podczas próby w Krakowie reżyser odmalował całkiem odmienny obraz tej sceny:

Ja poszedłem może za daleko, bo po prostu w samym finale sztuki [...] to on nawet brał koronę i nosił tę koronę na ostatku, mówiąc, jak to szlachetny Hamlet i tak dalej, i tak dalej. Tamten oczywiście odbierał mu koronę i wkładał sobie sam. No i brali go od tyłu - ciach! Ostatniego świadka ${ }^{57}$.

Dostępne recenzje nie przekazują informacji o takim zakończeniu. Trudno zatem spekulować, czy recenzenci nie odnotowali przebiegu zdarzeń, czy Swinarski relacjonował sytuacje modelowane podczas prób, czy może słowami „poszedłem może za daleko" mówił o swojej wizji.

Odmiennie od tradycji ukazana została także postać Ducha ojca. Na podstawie opisów można stworzyć jej całkiem plastyczny obraz:

Kiedy w pierwszej scenie ukazuje się Duch zmarłego króla, nie jest to eteryczna zjawa unosząca się nad wałami, jak Duch w Hamlecie, którego widziałem, będąc w wieku dziewcząt i chłopców siedzących na galerii - ale ciężki trup - robot, ubrany w zbroję, z potwornie zgniłą twarzą ${ }^{58}$.

Należy również skrytykować wystąpienie Ducha ojca Hamleta, które było bardzo nieudane pod każdym względem. Opancerzony rycerz, który krążył po scenie, przypominał żenująco ostatni akt Don Giovanniego Mozarta ${ }^{59}$.

Akcja Hamleta przeciwko Klaudiuszowi [...] rozpoczyna się dopiero po tym, jak Duch ojca Hamleta pojawia się żywy, fizycznie i wzywa Hamleta do zemsty. Nie było to udane, gdy swego czasu w spektaklu w Habimie pojawiał się tylko cień Ducha i słychać było jego głos. To jednak przesada, gdy Swinarski teraz każe pojawić się Duchowi jednocześnie ze wszystkich stron, ubierając kilku statystów w taką samą szarą zbroję. [...] (Biedny Duch, który tak źle wykonał swoje zadanie, nie jest nawet wymieniony w programie) ${ }^{60}$.

Duch w zbroi, fizycznie obecny, ukazywał się z kilku stron naraz. Jego pojawienie się miało nie tylko służyć zawiązaniu intrygi, ale uruchamiać tworzenie się wielowymiarowych konstelacji znaczeń: psychologicznych (czy Duch manipuluje

\footnotetext{
6 Opalski, Rozmowy o Swinarskim.

57 Kuźnicka, "Swinarski na próbie”.

58 Kohansky, "Hamlet - sztuka siły".

59 Chusch, "Hamlet im Theatron Kameri".

60 Geis, „Kammertheater: Hamlet”.
} 
uczuciami Hamleta, usiłując wzbudzić współczucie?) i antropologicznych (czym/ kim jest Duch w świadomości współczesnych?). Ani w recenzjach, ani w programie izraelskim nie znajdujemy informacji o tym, kto grał tę postać, wiadomo tylko, że wystąpiło kilku statystów.

Poloniuszowi (Jehuda Fuchs) nie poświęcono zbyt wiele uwagi. Poza zdawkowymi ocenami, najczęściej przychylnymi: „to jedyna wyrazista, w pełni ukształtowana postac" "61, „przekonujący i żywy doradca”62, odnajdujemy tylko jeden ślad. Ewron zauważył, że Poloniusz coś notuje, „stanowi postać ze sfery handlu”63. Postaci królewskiego urzędnika przypisał Swinarski funkcję współtworzenia obrazu zasad działania państwa duńskiego zajętego handlem, wymianą i dyplomacją, a nie tylko rolę groteskowej przeciwwagi dla intelektu i bystrego dowcipu księcia.

Atrakcyjne role grabarzy i aktorów, które w historii teatru niejednokrotnie stawały się popisami, w Tel Awiwie, jak można wnosić ze skromnych przekazów, oceniane były rozmaicie. Nissan Jatir w podwójnej roli grabarza i aktora grającego królową jednym się podobał: „Jedyną osobą, która odniosła sukces w tej sztuce był Nissan Jatir”64, innym - nie: „Nissan Jatir jest predestynowany do sceny cmentarnej, szarżował jednak tak dalece, że o mało nie pogrzebał roli Pierwszego Grabarza”65. O grabarzach pisano: „Jedynymi rolami, które się udały, były te krótkie komiczne. Nie odbiegały od oryginału, gdyż reżyser nie wprowadzał w nich zmian”66. O aktorach inaczej: „Błędem było pozwolenie, aby sceny aktorów stanowiły w sztuce karykatury, zabawne przerywniki, ponieważ szczegółowe przedstawienie morderstwa króla musi mieć największe znaczenie"67.

Koncepcja scenografii, którą w Izraelu opracowali Swinarski i Eli Sinaj, zbliżona była do projektowanej w Krakowie przez Skarżyńskich. W obu wypadkach nawiązywała do konstrukcji sceny elżbietańskiej. Miała to być przestrzeń jednorodna, surowa, z otwieranymi centralnie skrzydłami ciężkiej bramy i podestem.

Scenograficzna koncepcja reżysera Swinarskiego zaskakiwała swoją oryginalnością: scena była właściwie bez rekwizytów, jak w oryginalnym teatrze z czasów Shakespeare’a, ale przecież łączyła w sobie elementy dekoracyjne, jak most zwodzony, przez który wchodzili aktorzy na scenę, jak utrzymana w archaicznym stylu mała kurtyna, która po podniesieniu tworzyła niejako barwny baldachim nad sceną ${ }^{68}$.

\footnotetext{
61 Jaron, "Hamlet metumcat".

62 Marton, "Kameri Szinház: Hamlet".

63 Ewron, „Mawet u-mischar”.

64 Marton, "Kameri Szinház: Hamlet”.

65 Dr. H.R., "Hamlet", Przegląd, 5 maja 1966

66 Ewron, „Mawet u-mischar”.

67 Geis, „Kammertheater: Hamlet”.

68 Schlang, "Hamlet".
} 
W scenie otwierającej, na tarasie pałacu w Elsynorze, zbudowane są mury po prawej i po lewej stronie, pośrodku podwójna brama, do której prowadzą trzy stopnie i most zwodzony, który czasami jest głośno przesuwany. [...] Dopiero na samym końcu, kiedy pojawia się zdobywca Fortynbras, mury znikają, aby pokazać cały arsenał broni i amunicji, który ma szczególnie podkreślić klęskę królestwa, którego wszyscy książęta leżą tutaj zamordowani, zboczywszy z praworządnej drogi 69 .

Można jeszcze dodać kilka szczegółów: wspomniany gobelin według jednego recenzenta zdobiony był „herbami”, u innego „mylącą obfitością quasi-symboli” 70. Ten ostatni autor zauważył również, że w końcowej scenie opadające z prawej i lewej strony ściany to „worki zrzucane z drewnianych konstrukcji”, co daje wyobrażenie materialnej faktury stworzonego świata. W Krakowie Swinarskiemu zależało na użyciu szlachetnych surowców: ciemnego, starego drewna, skóry, naturalnych tkanin.

\section{Co może wchłonąć gąbka?}

Próby sformułowania uogólnionej interpretacji inscenizacji Swinarskiego podjęło niewielu autorów. Odnajdujemy w tekstach przede wszystkim informacje o klasycznych odczytaniach dzieła, jego najważniejszych w historii wystawieniach, miejscu premiery w życiu kulturalnym Izraela, a także ocenę gry aktorów. Określając charakter przedstawienia polskiego reżysera, używano pojęć „współczesne”, „polityczne”, „umiejscowione historycznie”: „Sprawy polityczne, chciałoby się powiedzieć - choć może nieco przesadnie - postawiły bohatera tytułowego w cieniu, zwłaszcza w pierwszej połowie spektaklu, przed przerwą"71.

Pogłębione refleksje pojawiły się w dzienniku „Dawar”72. Recenzent najpierw dostrzegł w wizji Swinarskiego: „dramat humanizmu pozbawionego Boga”: „Hamlet nie powtarza, że «Bóg umarł», ale stara się rachunki ze światem załatwić bez Boga. Monolog to potwierdza”. Zauważył też, że reżyser: „porzuca romantyczną melancholię, która Hamleta okrywała w przeszłości. Dramat polityczny, który wystawia, zdejmuje ze sztuki splendor. Świadczą o tym i scenografia, i kostiumy”. Polityczny charakter interpretacji krytyk wiązał z intelektualnym przygotowaniem i pochodzeniem reżysera.

\footnotetext{
69 Geis, „Kammertheater: Hamlet”.

70 Chusch, "Hamlet im Theatron Kameri".

71 Chusch.

72 "Hamlet ha-rewii szeli".
} 
Polska zawsze była wrażliwa na postać Hamleta. Mickiewicz widział ją w jego osobie. Nic dziwnego, że Konrad Swinarski, Polak, przyjął linię polityczną i wydobył aspekt intelektu, który radzi sobie przez działanie. Nie tylko po to, żeby zrozumieć, ale też po to, by zmienić. Nieprzypadkowo objawia się w tym duch Brechta. Jest to widoczne w estetyce i skłonnościach reżysera, nie tylko w aspektach etyczno-politycznych.

Krytycy izraelscy, choć nie brakło życzliwych Swinarskiemu (np. „Izraelskie Nowiny i Kurier"), nie ukrywali braku przygotowania do odbioru teatralnego nowatorstwa. Ewron przyznawał: „Dopiero zakulisowa rozmowa z kimś, kto znał intencje reżysera, wyjaśniła mi, o co chodzi”"73.

Jednak u nas stwierdziliśmy dwukrotnie na przykładzie Kupca weneckiego (raz w reżyserii Jessnera, a raz Tyrone Guthriego), że eksperymenty reżyserów, które mogą się podobać w Londynie i Berlinie, nie mogą liczyć na zrozumienie widzów, którzy nie doceniają ,wariacji na temat Shakespeare’a", ponieważ jeszcze długo nie będą w stanie samodzielnie opanować tematu. Można byłoby zrobić próbę na przykład i zapytać po każdym przedstawieniu Teatru Cameri stu nieprzygotowanych widzów, którzy wcześniej nie znali Hamleta (a tylu chyba jest każdego wieczora), o kontekst i jednoznaczną fabułę sztuki. Zaledwie dziesięć procent respondentów będzie w stanie udzielić zadowalającej odpowiedzi ${ }^{74}$.

To przedstawienie mimo niedostatków wysoko wyrasta ponad poziom teatru, w którym funkcjonujemy. Byłoby dobrze, gdyby młodzi wychowywali się na tym dramacie i świetnym tekście Szlonskiego. Kiedy Shakespeare ich wychowa, może jakiś izraelski reżyser rzuci inne światło niż ważny polski artysta ${ }^{75}$.

Przedstawienie stało się tematem specjalnego wieczoru zorganizowanego przez Zionist Organization of America (Amerykańską Organizację Syjonistyczną)76. Pełna sala wysłuchała wykładu profesora Murraya Rostona, anglisty z Uniwersytetu Bar-Ilan. Zasadniczą część tego wystąpienia stanowiła analiza niepokoju Hamleta, interpretowanego w kontekście przeobrażeń światopoglądowych epoki, także tych związanych z protestantyzmem. Roston dowodził, że charakter oraz wahania księcia Danii wytłumaczyć można rozdarciem pomiędzy wiarą i rozumem. Przedstawił również przegląd historycznych ujęć postaci księcia od romantyzmu po egzystencjalizm, freudyzm i koncepcję Jana Kotta. Uznając, iż miarą wartości spektaklu jest wierność tekstowi, Roston stwierdził, że interpretacja Swinarskiego, który usunął z utworu wszystko, co nie pasowało do jego idei, stanowiła

\footnotetext{
73 Ewron, "Mawet u-mischar".

74 Geis, "Kammertheater: Hamlet".

75 "Hamlet ha-rewii szeli".

${ }^{76}$ Relację ze spotkania opublikowano w Z.O.A. House News, maj/czerwiec 1966.
} 
zaprzeczenie Hamleta. Z Rostonem dyskutował Szimon Bar. Tłumaczył, że Swinarski jako nowoczesny artysta może skracać tekst, mając na względzie czas trwania przedstawienia i korzystając $\mathrm{z}$ prawa reżysera do interpretowania utworu zgodnie z wymogami współczesności. Bar deklamował też fragmenty swej roli i opatrywał je komentarzami.

Przywołane izraelskie recenzje są bez wątpienia zróżnicowane. W niektórych dominują kalki interpretacyjne podszyte emocjonalnym stosunkiem do przedstawienia. W innych pojawia się pogłębiony i mniej schematyczny namysł nad inscenizacją, połączony $z$ akcentowaniem jej oryginalności. W obu typach recenzji utrwalone zostały cenne informacje o przebiegu dzieła, z których wynika, że już w 1966 roku Swinarski miał ugruntowaną koncepcję Szekspirowskiej tragedii i sprawdził wiele pomysłów na jej teatralne ucieleśnienie.

\section{Krakowskie echa izraelskich doświadczeń}

Zestawienie niedokończonej, przerwanej tragiczną śmiercią reżysera inscenizacji Hamleta w Krakowie ze spektaklem zrealizowanym w Tel Awiwie jest zabiegiem właściwie nieuprawnionym. Porównywanie dwóch realizacji scenicznych zawsze budzi sprzeciw ze względu na szacunek dla autonomii dzieł i na wielość kontekstów i uwarunkowań, w jakich one funkcjonują. W przypadku obu prac Swinarskiego pozostał zachowany w różnych przekazach projekt ideowy oraz zarys wizji świata i kształtu postaci. W kilku punktach, jakkolwiek dotyczących spraw ogólnych, ukazujących raczej perspektywę czy kierunek interpretacji niż konkret, koncepcje Swinarskiego realizowane w Cameri i w Starym były podobne. Jak już wspomniano we wstępie, artysta przywoływał izraelskie przedstawienie podczas prób w Krakowie i wyraźnie podkreślał ciągłość swojego myślenia o dramacie.

Widział przede wszystkim konieczność gruntownego przewartościowania koncepcji historiozoficznej, a co za tym idzie społecznej, politycznej i psychologicznej dramatu. Rozpoczynając próby w Starym wyznawał:

Ale interpretacja pewnych postaci w tym utworze, którą ja częściowo wypróbowałem, powiedzmy w poprzednim przedstawieniu, jest niesłychanie bardziej skomplikowana, niż to dotychczas, że tak powiem, bywało w przedstawieniach ${ }^{77}$.

I dalej:

Od czego ja wychodziłem przy, przy, w ogóle przy pierwszym przedstawieniu, po prostu od tego, że ja nie wierzę w to, co zawsze widywałem w teatrze, że Hamlet był

77 Kuźnicka, „Swinarski na próbie", 8. 
dobry, Król był zły, a coś było, latało dookoła tego, mniej lub bardziej upolitycznione, czy... czy uzmysłowione i na końcu był finał operowy, że wchodził ktoś i oświadczał, że i tak przypadek wygrywa ${ }^{78}$.

Radykalna reinterpretacja Szekspirowskiej tragedii, odrzucenie głęboko zakorzenionych w kulturze i uwewnętrznionych przez wielu widzów schematów pojęciowych wymagało, zdaniem artysty, nowych przekładów sztuki. I w Tel Awiwie, i w Krakowie, jakkolwiek z innych powodów, Swinarski pracował na nowych tekstach: Abrahama Szlonskiego w Cameri i Macieja Słomczyńskiego w Starym. Nowa szata językowa dramatu miała pomóc przenieść na scenę odkrywcze odczytanie tragedii.

W Hamlecie widział Swinarski przesilenie dwóch epok: odchodzącego, rządzącego się prawem wojny feudalizmu i nowej ery, w której królować mają zasady dyplomacji i handlu. W Tel Awiwie uwidocznione to zostało w scenografii i działaniach scenicznych, a także w sposobie ukształtowania postaci Klaudiusza i Poloniusza. W Krakowie Swinarski mówił wyraźnie, że wizja historii, która poruszała jego wyobraźnię, ugruntowała się podczas pracy w teatrze Cameri, a punktem jej wyjścia był pomysł „podziału w Hamlecie na jak gdyby trzy epoki"79. Trzy epoki, które planował odmalować na scenie to: feudalizm uosobiony przez starego Fortynbrasa i starego Hamleta, okres monarchii dyplomatycznej, którą miał reprezentować Klaudiusz, wreszcie epoka wyzwolonego humanizmu istniejąca przede wszystkim w Hamlecie. Swinarski dodawał, że „rzecz wraca na końcu właściwie do tej pierwotnej przez podbój" ${ }^{80}$. Militarny aspekt okresu feudalnego związany z panowaniem starych królów i młodego Fortynbrasa obrazował w Cameri potężny arsenał uzbrojenia ukazujący się w finale spektaklu. W Krakowie obecność wojska (już to na placu Szczepańskim, już to wewnątrz teatru) miała się stać dominantą znaczeniową. Jerzy Skarżyński mówił wręcz o „totalnym opanowaniu teatru przez soldaterię"81. Z kolei pokojowa epoka dyplomacji i handlu reprezentowana była (i miała być) przez Klaudiusza i Poloniusza. Zasadniczy obraz głównych postaci, wpisany w wizję przeobrażeń epok, był więc w wyobraźni Swinarskiego ugruntowany.

Sprawę króla Klaudiusza opisywał między innymi słowami: „ten nowy król, który chce prowadzić państwo dzięki dyplomacji”, i dalej:

Ja zawsze musiałem w Izraelu dawać przykłady z życia, oni są do tego przyzwyczajeni, więc ja po prostu dałem im taki przykład z życia, że istnieją zabójstwa, które dla społeczeństwa wydają się moralnie usprawiedliwione. [...] Więc wydaje mi się, że zabójstwo

\footnotetext{
78 Kuźnicka, 8.

79 Kuźnicka, 8.

80 Kuźnicka, 8.

81 Opalski, Rozmowy o Swinarskim, 64.
} 
Klaudiusza, znaczy morderstwo przeprowadzone na starym królu, ma swoje moralne uzasadnienie. W czym? Chyba w racji stanu ${ }^{82}$.

Rysował wstępny obraz psychologicznej złożoności postaci, podkreślając „poczucie winy” władcy, a także projektując całkiem nowe odczytanie relacji łączących Hamleta ze stryjem, w których widział potencjalnych partnerów politycznych i „w ogóle dwie najbliższe sobie osoby”"83. Omawiane wyżej recenzje i artykuły prasowe potwierdzają, że w Tel Awiwie Jadin stworzył postać odbiegającą od tradycyjnych ujęć. Jego Klaudiusz nie był czarnym charakterem. Bar wspominał: „reżyser wyjaśnił mi, że Hamlet nawet rozumie Klaudiusza: Klaudiusz nie mógł postąpić inaczej"84. Istotny wymiar stosunków króla i księcia, którym tak wielką rangę nadawał reżyser w Krakowie, wyznaczony został zatem już w 1966.

Kolejny zbieżny punkt to koncepcja roli tytułowej. Wprawdzie kreacji Szimona Bara daleko było do pełnej rozmachu wizji, jaką osiem lat później tworzył Swinarski w Krakowie z Jerzym Radziwiłowiczem, nie ulega jednak wątpliwości, że odważne i nowe ujęcie, które aktor i zespół w Tel Awiwie wypracowali, zapowiadało kierunek myślenia reżysera. Figura Hamleta wyłaniająca się z izraelskich recenzji ma pewne punkty wspólne $\mathrm{z}$ obrazem postaci księcia zarysowywanym podczas prób w Starym. Miał być to Hamlet nie na miarę heroiczną, ale człowiek o złożonej, nietuzinkowej osobowości, wybitnym intelekcie, na wiele sposobów poraniony wewnętrznie. Zarówno w Krakowie, jak w Tel Awiwie formował Swinarski tę postać ze wszystkich teatralnych tworzyw, przede wszystkim poprzez ekspresję aktorską twórcy roli głównej, ale także przez relacje z innymi postaciami i wszystkie wymiary wykreowanego uniwersum. Ogromne znaczenie w tym aspekcie miały nowe tłumaczenia tragedii oraz sposób ukształtowania tekstu: w polskiej inscenizacji Swinarski zdecydował o wystawieniu całości utworu, w Tel Awiwie wprowadził obszerne skróty, obejmujące także wielkie monologi. Swoje decyzje w tej materii komentował po latach autoironicznie: „Ja akurat z przerażeniem stwierdziłem - pokreśliłem właściwie idiotycznie, mówiąc między nami, dziesięć lat temu"85. Najistotniejszym i zasadniczym rysem interpretacji aktorskiej miała być w Krakowie, podobnie jak Tel Awiwie, eliminacja patosu i obniżenie tonacji gry. Podczas pracy nad obiema inscenizacjami podejmowano też problem szaleństwa księcia. W obu wypadkach zauważono, że Hamlet nie jest chory umysłowo. Hamleta krakowskiego, jak wspominał Radziwiłowicz ${ }^{86}$, przy wybitnej inteligencji miała cechować właściwie neurasteniczna emocjonalność.

\footnotetext{
82 Kuźnicka, "Swinarski na próbie", 13 .

83 Kuźnicka, 13.

84 Rachel Oren, „Tysiąc twarzy księcia z Danii", tłum. Ewa Świderska, przekład artykułu z Dawar, 8 kwietnia 1966, cyt. za: Opalski, Rozmowy o Swinarskim, 265.

85 Kuźnicka, „Swinarski na próbie”, 7.

${ }^{86}$ Opalski, Rozmowy o Swinarskim, 189-232.
} 
Reżyser planował nawet umieścić w programie „jako swego rodzaju motto przedstawienia" odezwę Bądźcie pozdrowieni psychoneurotycy Kazimierza Dąbrowskiego ${ }^{87}$. Można snuć dywagacje, jak granicę między neurastenią a szaleństwem odmalowałby Radziwiłowicz, ale Bar wiedział, że książę wariatem nie był. W działaniach księcia widział też Swinarski wiele zła i chciał je ukazać na scenie. Radziwiłowicz wielokrotnie zastrzegał, że praca nad rolą była dopiero w fazie początkowej i wszystko, co pamięta, mogło być przez reżysera zmienione i rozumiane w szczególny sposób. Jednakże mroczna strona osobowości księcia stanowiła ważny wątek. Intrygującą poszlaką, która może wskazywać na intencję ukazania negatywnego oblicza Hamleta już przed laty w Izraelu, jest przywołana wcześniej informacja, że Swinarski przez chwilę rozważał wykorzystanie pomysłu Bara, aby książę miał ręce poplamione na czerwono. Hipotetycznie można to uznać za trop w poszukiwaniach ujęcia roli.

Już w Tel Awiwie przewartościowaniu uległo ujęcie roli Horacego, z której Swinarski był zadowolony. W interpretacji Josefa Grabera Horacy stał się prostym, pragmatycznym człowiekiem, którego z księciem niewiele łączyło i który po jego śmierci miał dobrze służyć nowemu władcy. Odnotowany przez recenzentów gest przekazania korony Fortynbrasowi odbierał Horacemu romantyczną aurę powiernika i strażnika pamięci Hamleta. W Krakowie reżyser mówił: „Ja nienawidziłem tego rezonera, który wciąż chodził i miał szlachetną minę przez cały czas, a ten głupi tutaj cały czas mu się tam zwierzał z tego"88. Podkreślał, że Horacy przyjeżdża do Elsynoru po posadę, że przyjacielem staje się mimo woli, a Hamlet zdaje sobie $\mathrm{z}$ tego sprawę. Ten zasadniczy punkt wyjścia artysta przyjął już w Cameri, jednakże w osobowości Horacego, nad którą pracował w Krakowie Jerzy Stuhr, miało się objawić dużo więcej wymiarów ${ }^{89}$.

Podobieństwo między przedstawieniem izraelskim a koncepcjami omawianymi w Krakowie można zauważyć także w sposobie ukazania Ducha starego Hamleta ${ }^{90}$. W obydwu wypadkach Duch występował w zbroi, był człowiekiem z krwi i kości, o twarzy koszmarnie zniekształconej rozkładem. W obydwu teatrach jego nadnaturalny wymiar podkreślało jednoczesne pojawianie się w kilku miejscach (dzięki zaangażowaniu kilku osób). W Krakowie Swinarski mówił, że zależy mu na formule barokowego teatru grozy ${ }^{91}$. Rozważał możliwość zastosowania efektów specjalnych w postaci iskier wyładowań elektrycznych przy dotknięciu ręki. Oprócz tego dywagował nad wprowadzeniem „podwójnej” obsady, by Ducha i Fortynbrasa grał ten sam

\footnotetext{
Opalski, 192

88 Kuźnicka, „Swinarski na próbie”, 10.

89 Opalski, Rozmowy o Swinarskim, 111-124.

90 Zob. też Olbinska, „Od izraelskich notatek do krakowskich nagrań”.

91 Kuźnicka, „Swinarski na próbie”, 50; Opalski, Rozmowy o Swinarskim, 79.
} 
aktor, co wskazywałoby na łączność ideową dwóch władców. Podążał tropem podjętym w Tel Awiwie.

Tak ważne postacie, jak Gertruda, Ofelia, Laertes, Rosencrantz i Guildenstern czy Ozryk i grabarze, które w kreacji krakowskiej tworzyć miały bogate, powiązane gęstą siecią znaczeniowe konstelacje, w prasie izraelskiej nie zostały opisane wcale lub potraktowano je mniej niż zdawkowo. Trudno zatem snuć domysły o rodzących się koncepcjach i wypróbowywanych zamierzeniach. Tymczasem nie tylko $\mathrm{z}$ informacji o krakowskich próbach wiadomo, jak wielką wagę przywiązywał reżyser do ról z pozoru mniej istotnych. Precyzyjnie skonstruowane pozwalały ukazywać wielowymiarowe relacje między bohaterami, ujawniać na nowo odkrywane motywacje, odmalować tło społeczne i kulturowe wydarzeń. Swinarski był mistrzem w budowaniu takich złożonych konstrukcji.

Zasadniczy żywioł jego pracy artystycznej, której sens polegał na bezpośredniej, wielowymiarowej relacji z ludźmi i przedmiotami, w Izraelu realizował się, jak można sądzić, tylko $\mathrm{w}$ niewielkim stopniu. Zachowany $\mathrm{w}$ przekazach obraz pracy krakowskiego zespołu pozwalał mieć w tej sferze większe nadzieje. Sensem istnienia teatru jest wpisywanie idei w żywą tkankę ludzi i świata, ale idee podlegają też werbalizacji i nazwane, wypowiedziane, zapisane pozostają najdłużej. W przypadku Hamleta Swinarskiego z nimi właśnie pozostajemy. Informacje z izraelskich recenzji i artykułów, jakkolwiek skromne, potwierdzają dotychczasowe przypuszczenia, że już w 1966 roku koncepcja Hamleta była ukształtowana w głównym zarysie, a osiem lat później miała być rozwijana i doprecyzowywana.

\section{Bibliografia}

Barzilai, Reut. „Being European: Hamlet On the Israeli Stage”. Multicultural Shakespeare: Translation, Appropriation and Performance 21, no. 36 (2020): 27-53. https:// doi.org/10.18778/2083-8530.21.03.

Kuźnicka, Danuta, oprac. „Konrad Swinarski na próbie Hamleta”. Pamiętnik Teatralny 28, Z. 1 (1979): 3-52.

Olbinska, Zuzanna. „Od izraelskich notatek do krakowskich nagrań: Wizja Ducha ojca w niezrealizowanym Hamlecie Konrada Swinarskiego". Twórczość, nr 11 (2019): $80-93$.

Opalski, Józef. Rozmowy o Konradzie Swinarskim i „Hamlecie”. Kraków: Wydawnictwo Literackie, 1988.

Sturm, Dieter. „Konrad Swinarski i teatr niemieckojęzyczny”. Rozmawiała Małgorzata Dziewulska. Tłumaczenie Dorota Krawczyk-Janisch. Teatr 49, nr 5 (1994): 7-15.

Swinarski, Konrad. „«Powinienem zmienić zawód»: Z korespondencji Konrada Swinarskiego". Teatr 54, $\mathrm{nr}$ 7-8 (2000): 68-70. 
Walaszek, Joanna. Konrad Swinarski i jego krakowskie inscenizacje. Warszawa: Państwowy Instytut Wydawniczy, 1991.

\section{Abstrakt}

\section{Izraelski "Hamlet" Konrada Swinarskiego}

Analiza nieznanych dotąd w Polsce recenzji, które ukazały się w izraelskiej prasie po premierze Hamleta w reżyserii Konrada Swinarskiego w Teatrze Cameri w Tel Awiwie w 1966 roku, pozwala nie tylko odtworzyć niektóre działania i efekty sceniczne, ale także prześledzić tok rozumowania krytyków, ich kompetencje i upodobania. Porównanie tych materiałów z dokumentami dotyczącymi przygotowań do inscenizacji Hamleta w Krakowie osiem lat później daje podstawę do stwierdzenia, że w 1966 artysta miał już ukształtowaną w zasadniczych rysach koncepcję Szekspirowskiej tragedii i niektóre jej aspekty udało się zrealizować w Tel Awiwie. Przede wszystkim wykreował nowy obraz postaci księcia i Horacego, poddał rewizji wizerunek króla Klaudiusza i zarysował historiozoficzno-polityczną interpretację tragedii. W Izraelu przekaz ideowy inscenizacji odczytywany był przez krytykę najczęściej właściwie, podważano jednak jego sens i negowano wartość.

\section{Słowa kluczowe}

Konrad Swinarski, Shakespeare, Hamlet, Teatr Cameri w Tel Awiwie, Stary Teatr w Krakowie

\section{Abstract}

\section{Konrad Swinarski's Israeli "Hamlet"}

This article discusses the Israeli press reviews of Konrad Swinarski's Hamlet, which premiered at the Cameri Theater in Tel Aviv in 1966. Based on material previously unknown in Poland, the analysis makes it possible not only to reconstruct some of the stage actions and effects, but also to follow the reasoning, competences and tastes of Israeli critics. Comparing this material with documents concerning the preparations for the Kraków staging of Hamlet eight years later, the author concludes that the general framework of Swinarski's conceptualization of the play was already developed in 1966; the director managed to bring some of its aspects to the stage in Tel Aviv. Most importantly, he created a new vision of the characters of Hamlet and Horace, re-examined the image of Claudius, and outlined a historiosophical and political interpretation of Shakespeare's tragedy. In Israel, the critics usually recognized the ideological message of Swinarski's staging correctly; however, they questioned its point and denied its value.

\section{Keywords}

Konrad Swinarski, Shakespeare, Hamlet, The Cameri Theater of Tel Aviv, Stary Teatr in Kraków 


\section{DANUTA KUŹNICKA}

teatrolożka, profesor i wicedyrektor do spraw naukowych w Instytucie Sztuki PAN. Zajmuje się inscenizacją współczesną ze szczególnym uwzględnieniem teatru plastyki oraz teatru tańca i ruchu. Prowadzi także prace nad teoretycznymi aspektami opisu spektaklu teatralnego. 